\title{
Chemical composition and ruminal degradation kinetics of white oat (Avena sativa L.) IPR 126
}

\author{
Composição química e cinética da degradação ruminal de aveia branca ("Avena \\ sativa” L.) IPR 126
}

\author{
RICACHESKI, Silvonei Tiago ${ }^{1}$; HENRIQUE, Douglas Sampaio ${ }^{1 *}$; MAYER, Lilian \\ Regina Rothe ${ }^{2}$; OLIVEIRA, Jhone Gleison $\mathrm{de}^{3}$; ROSLER, Jucemara Aparecida ${ }^{4}$; \\ FLUCK, Ana Carolina ${ }^{1}$
}

\author{
${ }^{1}$ Universidade Tecnológica Federal do Paraná, Programa de Pós-Graduação em Zootecnia, Dois Vizinhos, \\ Paraná, Brasil. \\ ${ }^{2}$ Universidade Tecnológica Federal do Paraná, Dois Vizinhos, Paraná, Brasil. \\ ${ }^{3}$ Universidade Estadual do Norte Fluminense Darcy Ribeiro, Programa de Pós-Graduação em Ciência \\ Animal, Campos dos Goytacazes, Rio de Janeiro, Brasil. \\ ${ }^{4}$ Zootecnista, Dois Vizinhos, Paraná, Brasil. \\ *Endereço para correspondência: douglas@utfpr.edu.br
}

\section{SUMMARY}

The present study aiming to determine the nutritional quality of oat (Avena sativa L.) IPR 126 in order to produce forage for ruminants. Four periods between harvests were used: 14, 21,28 and 35 days, distributed in randomized blocks with four replicates for each treatment. The variables evaluated were: the concentration of dry matter (DM), neutral detergent insoluble fiber (NDF), crude potein (CP), lignin, dry matter (DM), ash, ether extract (EE) and in vitro digestibility of dry matter obtained by measurement of gas production. The profile of gas production was adjusted to the logistic bicompartimental mathematical model. The variables and the parameters of the adjusted gas production curves were analyzed as repeated measurements through the PROC MIXED of SAS (version 9.0) and the restricted maximum likelihood (REML) as the method of estimation of parameters. Regression analysis was performed for the variables: DM, CP, EE, NDF, ash, and for the parameter $\mathrm{k}_{2}$ of the bicompartimental model. DM and NDF concentrations increased linearly, $\mathrm{CP}$, ash, and the estimations of the parameter $\mathrm{k}_{2}$ reduced linearly and the EE concentration showed a cubic behavior in function of the age of harvest. Lignin and other parameters of the Schofield model were not influenced by the age of harvest. The harvest interval influenced some chemical components and degradation rate of fiber carbohydrates, but do not interfere in lignin concentration. The forage with 21 days of cutting interval has the high nutritional value.

Keywords: digestibility, forage, nutritional value

\section{RESUMO}

O objetivo com este estudo foi determinar a qualidade nutricional da aveia (Avena sativa L.) IPR 126, a fim de produzir forragem para ruminantes. Foram utilizados quatro períodos entre os cortes: 14, 21, 28 e 35 dias, distribuídos em blocos casualizados com quatro repetições para cada tratamento. As variáveis avaliadas foram: a concentração de fibra insolúvel em detergente neutro (FDN), lignina, matéria seca (MS), cinzas, extrato etéreo (EE) e digestibilidade in vitro da matéria seca obtida pela medição da produção de gás. O perfil de produção de gás foi ajustado ao modelo logístico bicompartimental. As variáveis e os parâmetros ajustados às curvas de produção de gás foram analisados como medidas repetidas através do PROC MIXED do SAS (versão 9.0) e a máxima verossimilhança restrita (REML) 
como o método de estimação de parâmetros. A análise de regressão foi realizada para as variáveis: $\mathrm{MS}, \mathrm{PB}, \mathrm{EE}, \mathrm{FDN}$, cinzas, e para o parâmetro k2 do modelo bicompartimental. As concentrações de MS e FDN aumentaram linearmente, $\mathrm{PB}$, cinza, e as estimativas do parâmetro $\mathrm{k}_{2}$ diminuíram de forma linear e a concentração de EE apresentou comportamento cúbico em função da idade de colheita. A lignina e outros parâmetros do modelo de Schofield não foram influenciados pela idade de colheita. O intervalo de colheita influenciou alguns componentes químicos e taxa de degradação de carboidratos de fibra, mas não na concentração de lignina. A forragem com 21 dias de intervalo de corte apresentou maior valor nutricional.

Palavras-chave: digestibilidade, forragem, valor nutritivo

\section{INTRODUCTION}

Oat is an annual winter grass with great nutritive value due its high digestibility and protein content. Additionally, oat has a high adaptability and genetic variability (OLIVEIRA, 2002).

The breeding and selection programs of white and yellow oats produced new varieties with dual-purpose characteristics (forage production and grains) that increased its use (CARVALHO et al., 2010). The development of new cultivars with longer vegetative cycles allows the utilization of oat in animal production systems (FLOSS et al., 2007). One example of these new oat cultivars is the IPR 126, breeding in 2005 by the Instituto Agronômico do Paraná (IAPAR, 2007). This variety provides forage supply for longer winter, and is suited for forage production, crop rotation and soil cover for tillage (IFPR, 2012).

The nutritional quality of the forage is probably the most important factor in the productivity of ruminants on pasture. Forage should have high nutritional value to provide most of the nutrients required for grazing animals
(PAULINO et al., 2002). Thus, the identification of possible factors that constrain animal production, and consumption of nutrients depend on the nutritional evaluation of the forage (VAN SOEST, 1994). During development and differentiation of oat changes occur in its vegetative and reproductive organs that determine the amount of biomass produced, and the chemical composition of the plant. These changes influence directly the digestibility and utilization of the nutrients by the animals (RIZZI et al., 2004). In this context, the objective of this research was to evaluate the effect of the harvest interval on the chemical composition and kinetics of rumen degradation in white oat (Avena sativa L.) cultivar IPR 126.

\section{MATERIALS AND METHODS}

This research was conducted in Dois Vizinhos, located on the third plateau of Paraná, with an altitude of $520 \mathrm{~m}$, latitude $25^{\circ} 44^{\prime}$ south and longitude $54^{\circ}$ 04' west, where the climate is mesothermal humid subtropical (Cfa), according to Köppen (Maak, 1968). The implantation of oat (Avena sativa) variety IPR-126 was carried out mechanically, on April 18, 2012, with spacing between lines of $17 \mathrm{~cm}$, with $60 \mathrm{~kg} \mathrm{ha}{ }^{-1}$ seed. Four harvest interval were analyzed, 14, 21, 28 and 35 days distributed randomly into four blocks. The area of each plot was $25 \mathrm{~m}^{2}$. The first cut was made as a form of standardization for all treatments, at 49 days after planting, when the plants reached an average height of $27.5 \mathrm{~cm}$.

The fertilization was made mechanically at the time of deployment of oats containing $15 \mathrm{~kg} \mathrm{ha}^{-1} \mathrm{~N}, 75 \mathrm{~kg}$ $\mathrm{ha}^{-1}$ of $\mathrm{P}_{2} \mathrm{O}_{5}$ and $45 \mathrm{~kg} \mathrm{ha}^{-1} \mathrm{~K}_{2} \mathrm{O}$. Subsequently was held top dressing by 
hand, with three applications of $20 \mathrm{~kg}$ $\mathrm{ha}^{-1}$ of $\mathrm{N}$ as urea, the first immediately after cutting of standardization and the two subsequent at 28 and 56 days after the first application. The harvest of the samples were performed on the day determined for each cut to $10 \mathrm{~cm}$ of soil, being delimited one square meter $\left(\mathrm{m}^{2}\right)$ to the center of each plot and samples sent to partially dry matter determination.

The chemical analyzes performed were: insoluble neutral detergent fiber (NDF) by the method of Mertens et al., (2002); Klason lignin (LIG) and crude protein (CP), according to Van Soest \& Robertson (1985). Dry matter (DM), ash, and ether extract were determined by using the methodology described by Silva \& Queiroz (2002). The in vitro digestibility was determined following all recommendations of Abreu et al. (2014). Pressure and volume of gas were measured at $1,2,3,6,8,10,12$, $16,20,24,30,36,48,72$, and $96 \mathrm{~h}$ of post-incubation. The volume readings were expressed in mL/0.1 g DM. After the incubation period, it was verified the $\mathrm{pH}$ of the samples with a digital pHmeter (PH-206 LUTRON) support.

For degradation rate adjustment, gas production data was fitted using a bicompartimental model (SCHOFIELD et al., 1994):

$$
V f=\frac{V f_{1}}{1+\exp ^{\left[2-4 k_{1}(t-\lambda)\right]}}+\frac{V f_{2}}{1+\exp ^{\left[2-4 k_{2}(t-\lambda)\right]}}+e
$$

in which $V f=$ total gas volume $\left(\mathrm{mL} \mathrm{g}^{-1}\right.$ degraded MO) in time $t ; V f_{l}=$ maximum volume of gas produced by the degradation of the soluble fraction of rapid digestion; $V f_{2}=$ maximum volume of gas produced by the degradation of the potentially degradable insoluble fraction of slow digestion; $k_{l}=$ specific rate of gas production by degradation of the soluble fraction of rapid digestion; $k_{2}=$ specific rate of gas production for degradation of potentially degradable insoluble fraction of slow digestion; $t=$ incubation time; exp $=$ is the base of natural logarithms; $\lambda=$ lag phase (lag time); $e=$ experimental error associated with each observation, supposed $\sim$ NIID $\left(0 ; \sigma^{2}\right)$. Parameters settings in the bicompartimental logistic model were estimated by NLIN procedure of SAS ${ }^{\circledR}$ (version 9) with the iteractive Marquardt method. To verify the influence of the treatments (harvest interval) on all parameters evaluated the analysis of repeated measures was used through the methodology of mixed models using PROC MIXED of SAS ${ }^{\circledR}$ (version 9), and the restricted maximum likelihood (REML) as estimation method. Four structures of variance and covariance matrix were tested: variance components (VC), composed symmetry (CS), auto regressive of first order (AR1) and unstructured (UN) (LITTELL et al., 2006). The residual variance and covariance structure most appropriate for all the variables was the VR chosen considering the lowest value of the Akaike Information Criterion corrected (AICC). Where the effect of treatment was considered significant, parameters were subjected to regression analysis (PROC REG) of SAS ${ }^{\circledR}$ program (version 9).

Data were analyzed using the statistical model:

$$
y_{i j k}=\mu+\alpha_{i}+b_{j}+a b_{i j}+\tau_{k(i)}+e_{l(i j k)}
$$


where $\mu$ is the overall mean; $\alpha_{i}$ is the effect of treatment, where $i=1,2,3$ and 4 to rest days 14, 21, 28 and 35 days respectively; $b_{j}$ refers to the effect of the block where $\mathrm{j}=1,2,3$ and $4 ; \tau_{k(i)}$ is the order of cut, and $\mathrm{k}=1$ to 6 for the treatment 14 days $\mathrm{k}=1$ to 4 for the treatment 21 days, $\mathrm{k}=1$ to 3 to $28 \mathrm{~d}$ and $\mathrm{k}$ $=1$ to 2 for the treatment 35 days; $a b_{i j}$ is the interaction of treatments with the block; and $e_{l(i j k)}$ refers to the variance error $\mathrm{V}\left(0, \mathrm{~V} \sigma^{2} \mathrm{e}\right)$ and $\mathrm{V} \sigma^{2} \mathrm{e}$ the variance and covariance matrix that is modeled.

The VC was the most suitable matrix for all variables studied. The VC matrix predicts a variance and covariance structure with no correlation among observations of the same experimental unit evaluated at different occasions over time (LITTELL et al., 2006). The UN matrix predicts a correlation among the information obtained over time, but without a mathematical model to express this correlation. The CS structure predicts a fixed correlation value over time and the matrix AR (1) estimates a correlation that is higher in adjacent measures and decreases as a function of the time interval between measurements (LITTELL et al., 2006). The best choice for the variance and covariance structures was the VC matrix for all variables in study.

The estimate of the confidence interval (95\% CI) for the mean of the dependent variables $\bar{y}$ was determined as follow: $\bar{y}=$ $\pm(U r-L r) / 2$ where $U r$ and $L r$ are respectively the upper and lower limit of $95 \%$ CI. $U r$ was calculated as $\bar{y}+$

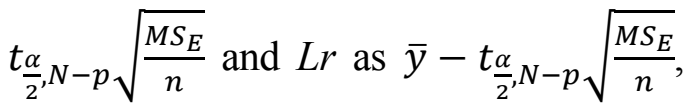
in which $t$ is the probability distribution $(\alpha=0.05$ and $N-p$ degrees of freedom, being $N$ the total number of observations and $p$ the number of treatment levels), $M S_{E}$ is the mean squared error and $n$ the number of replicates for each treatment (MONTGOMERY, 2005).

\section{RESULTS AND DISCUSSION}

The variables affected by treatments were shown in the Table 1 . The significance criterion $(\alpha)$ chosen was 0.05 . The concentrations of DM and NDF increased linearly as a function of regrowth interval. This result is expected, because aging reduces the water content of plant cells and increases the fiber concentration in the cell wall (PACIULLO, 2002; CASTRO et al., 2010). Kozloski et al. (2005) report that maturity is the primary factor for the decline of nutritional quality in forages, wich present a great variation in chemical composition, reflecting the degradation rate of compounds (VAN SOEST et al., 1991; VAN SOEST, 1994), especially the fibrous contents, which will negatively influence the rate of degradation. As the NDF content increases, the degradation rate of DM will decrease because of the difficulty of breaking these molecules by the bacteria, affecting the passage rate, due to the lower the rate of degradation. (KOZLOSKI, 2012).

Added to fiber, the protein content available for the ruminal microbiota is a limiting factor for its proliferation and digestion. The CP decreased linearly with the increase in the harvest period. Buxton (1996) describes that the increase between time and harvesting can result in a lower soluble content of the cell wall, reducing the percentage of leaves due to the physiological rangement and to the process of tissue differentiation that occur with the aging of the plant. With harvest, the protein will be fewer available due to thickening of the cell wall (VAN SOEST, 1994), mainly due to the high content of Phenolic compounds, such as lignin, have a direct reduction in $\mathrm{CP}$ contents, rapidly decreasing the 
nutritional quality (DESCHAMPS, 1999; GRIFFTHS \& BURNS, 2004).

Table 1. $\mathrm{P}$ values for the days of rest effect on nutritional characteristics of white oat (IPR 126)

\begin{tabular}{lc}
\hline Variables & P-value \\
\hline Dry matter $^{1}$ & $<0.0001$ \\
Crude protein $^{2}$ & $<0.0001$ \\
Fat $^{2}$ & $<0.0001$ \\
Neutral detergent & 0.0002 \\
fiber $^{2}$ & 0.6813 \\
Lignin $^{2}$ & $<0.0001$ \\
Ash $^{2}$ & 0.7514 \\
$V f_{1}$ & 0.9127 \\
$k_{1}$ & 0.0450 \\
$k_{2}$ & 0.4988 \\
$V f_{2}$ & 0.2372 \\
$\lambda$ & \\
\hline$V f_{1}$ and $V f_{2}$ are fast and slow gas productions, \\
$\left(\mathrm{mL} / 0.1\right.$ g DM); $k_{1}$ and $k_{2}$ are fractional rates of \\
the fast and slow pools, respectively; $\lambda$ is the \\
lag time in (hours). \\
${ }^{\text {g.kg }}{ }^{-1}$ as fed; ${ }^{2}$ g.kg ${ }^{-1}$ of dry matter.
\end{tabular}

Furthermore, it is necessary to understand the forage phenological cycle to identify the best time to perform cutting or grazing, aiming at better nutritional quality. It is worth mentioning the importance of providing a minimum $\mathrm{CP}$ for the maintenance of normal microbial fermentation in the rumen. However, PC content of white oats was much higher than the minimum value of $60 \mathrm{~g} \mathrm{~kg}^{-1} \mathrm{DM}$ in all harvest periods (Table 2).

The decrease in digestibility of forage cell walls along the aging of the plant is well known (PIRES et al., 2006; VIEIRA \& FERNANDES, 2006) and one of the factors associated with this phenomenon is the increase of lignin encrusted in cell wall nutrients (VAN SOEST, 1994; NRC, 2001; TOMICH et al., 2003; SILVA et al., 2007), However, the lignin contents did not change according to the days of regrowth (Table 2).

Table 2. Chemical composition of white-oat IPR 126. Average values and $95 \%$ confidence interval for each period of harvest

\begin{tabular}{lcccc}
\hline \multirow{2}{*}{ Variables } & \multicolumn{4}{c}{ Period of harvest (days) } \\
\cline { 2 - 5 } & 14 & 21 & 28 & 35 \\
\hline Dry matter $^{1}$ & $111 \pm 2.5$ & $127 \pm 6.5$ & $180 \pm 26.6$ & $204 \pm 16.8$ \\
Crude protein $^{2}$ & $239 \pm 9.2$ & $253 \pm 20.0$ & $185 \pm 24.0$ & $172 \pm 23.3$ \\
Fat $^{2}$ & $43 \pm 3.1$ & $45 \pm 3.7$ & $31 \pm 2.5$ & $27 \pm 3.2$ \\
Neutral detergent fiber $^{2}$ & $489 \pm 23.9$ & $522 \pm 17.2$ & $558 \pm 32.5$ & $602 \pm 80.8$ \\
Lignin $^{2}$ & $30 \pm 3.0$ & $32 \pm 6.1$ & $29 \pm 5.8$ & $28 \pm 6.8$ \\
Ash $^{1}{ }^{1}$ g.kg $^{-1}$ as fed;
\end{tabular}

The regression analysis was performed only on the variables: $\mathrm{DM}, \mathrm{CP}$, fat, NDF, ash, and the parameter $k_{2}$ (Table 3). The contents of DM and NDF increased linearly as a function of days of regrowth of oats, while the concentrations of $\mathrm{CP}$ and ash decreased linearly as well as the estimates of parameter $\mathrm{k}_{2}$ also decreased linearly as a function of treatment (Table 3). The concentration of fat varied cubically with increasing in time of regrowth, which indicates a sigmoid like decreasing pattern for this variable. 
Lignin and other kinetic parameters of degradation, except for the parameter $k_{2}$, did not vary significantly as a function of cutting intervals (Table 1). The cubic regression of EE (Table 3) in function of days of harvest may indicate that this variable declining in a sigmoid pattern. According to Van Soest (1994) most of the ether extract in forage leaves is formed by galactolipids and the remainder is composed of waxes, chlorophyll and other ether soluble substances. The ruminal degradation of galactolipids results in the release of fatty acids, glycerol and galactose.

Table 3. Regression equations and $p$ values of the chemical composition variables and degradation model parameters

\begin{tabular}{|c|c|c|}
\hline Variables & Regression equation & $\mathrm{P}$ value \\
\hline Dry matter $^{1}$ & $y=41.3557+4.6619 x$ & $<0.0001$ \\
\hline Crude protein ${ }^{2}$ & $y=297.43-3.4639 x$ & $<0.0001$ \\
\hline $\mathrm{Fat}^{2} \mathrm{P}-\mathrm{a}$ & $y=-116.01+22.576 x-0.982 x^{2}+0.01296 x^{3}$ & 0.0016 \\
\hline Neutral detergent fiber ${ }^{2}$ & $y=415+5.208 x$ & $<0.0001$ \\
\hline $\mathrm{Ash}^{2}$ & $y=133.22-2.1396 x$ & $<0.0001$ \\
\hline$k_{2}$ & - & 0.0123 \\
\hline
\end{tabular}

The glycerol and galactose are energy sources for the microbes, while fatty acids are usually biohydrogenated in the rumen and subsequently absorbed in the small intestine. However, waxes, chlorophyll and other ether-soluble substances account for about 39\% of total ether extract in leaves and do not contribute to the supply of energy to the rumen microbes or for the ruminant metabolism itself. Perhaps for this reason, and because the EE content of forage (except oilseeds, commonly used in the production of concentrated feed) is quite small (around $30 \mathrm{~g} \mathrm{~kg}^{-1} \mathrm{DM}$ ) in most papers the concentration of the plant EE was not investigated (MOREIRA et al, 2007; SILVA, 2011b; SMITH et al., 2013). But, despite all the peculiarities of this nutrient, it is necessary to quantify it to calculate the total carbohydrate of the feed (SNIFFEN et al. 1992; FOX et al., 2004).
The mathematical model of Schofield et al. (1994) was fitted to the gas production data for each one of the samples, generating a total of 60 gas production curves. The quality of fit was good to all profiles. Just to illustrate the goodness of fit the second cut of the block 2 was chosen to graphically represent all treatments (Figure 1).

The gas production curve describes a sigmoid pattern formed by an initial lag phase, defined in Schofield et al. (1994) model by the parameter $\lambda$, followed by an exponential increase in gas production until reaching the asymptotic phase (Figure 1).

The period of time between the sample incubation and the start of production of gas from microbial fermentation, that is, the time that microorganisms require to adhere to the substratum particle and begin to degrade it, is known as lagtime ( $\lambda$ ) (McALLISTER, 1994), and depends on the hydration of the particles, the anatomy of the plant and the microbial 
mass in the rumen (JUNG \& ALLEN, 1995). Initially, Schofield et al. (1994) presented a model with two lagtimes, one for each type of carbohydrate pool (fibrous and non-fibrous) to be fermented by the rumen microorganisms, however, the authors suggest a modification in the model assuming one lagtime for both substrates to reduce the number of parameters from six to five without losing quality of fit.
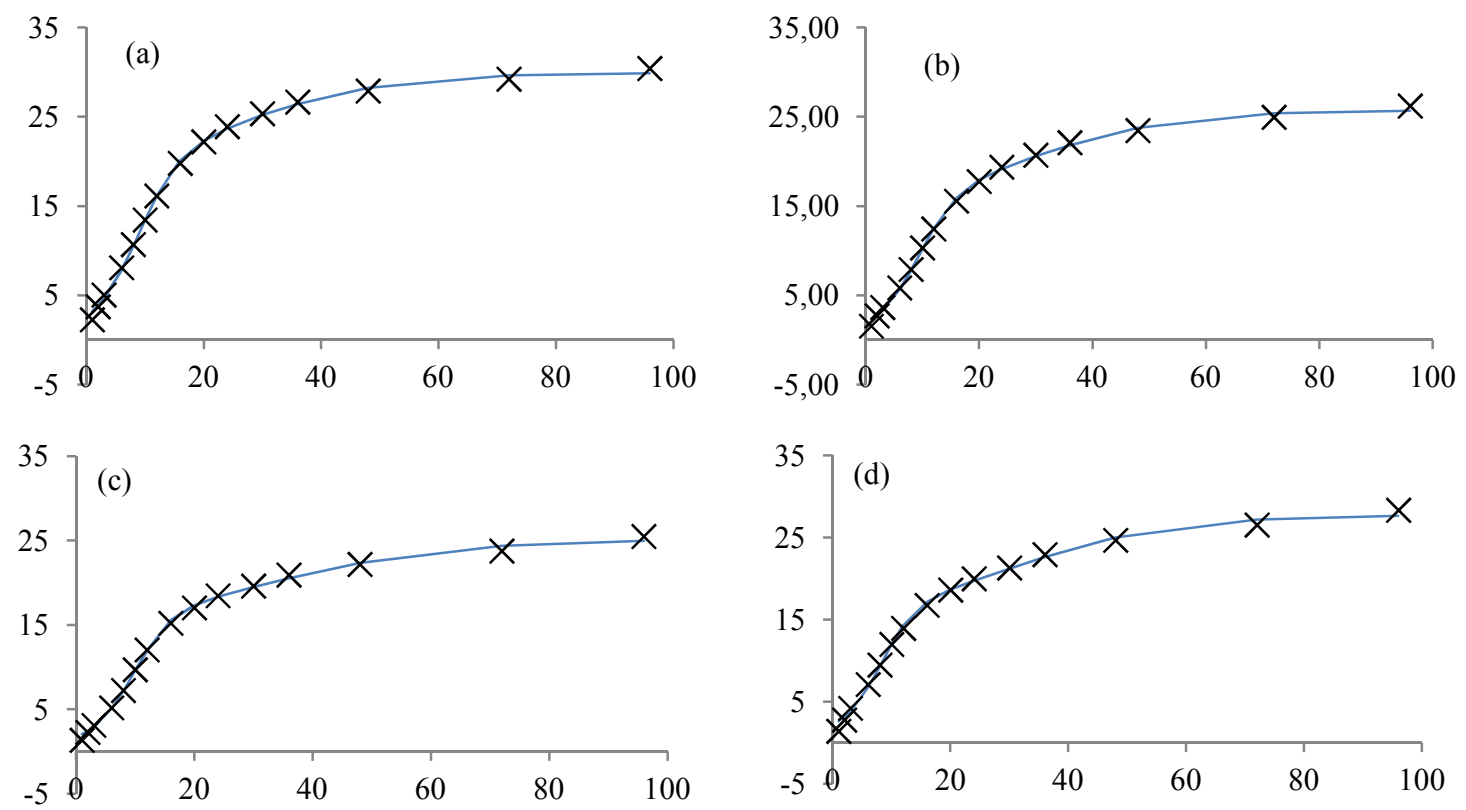

Figure 1. $\mathrm{X}$ axis - Incubation time (h); Y axis - Gas volume (mL/0.1g DM). Observed values of cumulative gas production by the dry matter in vitro degradation $(\times)$ and fitted curves. Panels: (a), (b), (c) and (d) for 14, 21, 28 and 35 days of harvest interval, respectively

Detmann et al. (2009) reported that the common lag time to both compartments of digestion may be related to the fiber fraction, which is directly related to most of the events involved in lagtime. The same authors also found higher lagtime values in the ages at which lignin and NDF were larger, agreeing with McAllister et al. (1994), who mention that factors related to the substrate, such as degree of lignification and protection of the cuticle, making out a barrier to adhesion and degradation. However, in this study was not observed variation in lagtime or lignin among different harvest ages, although there was a linear increase in NDF (Table 2 and 3 ).

In all curves fitted the value estimated to the parameter $\mathrm{k}_{1}$ was higher than $\mathrm{k}_{2}$, as expected, that means, non-fibrous carbohydrates degrade faster than fiber carbohydrates (SCHOFIELD et al, 1994, MALAFAIA et al., 1998). Although the estimates of $\mathrm{k}_{1}$ were not influenced by cutting interval the $\mathrm{k}_{2}$ decreased linearly with increasing maturity of oats (Table 4).

Henriques et al. (2007), evaluating the ruminal degradation kinetics of the forages Setaria grass (Setaria anceps Stapf), Hemarthria (Hemarthria altissima [Poir] Stapf. and Hubbard), 
Angola (Brachiaria purpurascens [Raddi] Henr.) and Acroceres (Acroceras macrum Stapf.) and its carbohydrate fractions and found a reduction in the proportion of potentially degradable carbohydrates as the plant age progresses. This corroborates the reduction in parameter $k_{2}$ with the increase of harvest interval (Table 3 ). Velasquéz et al. (2009), evaluating this same parameter in tropical forages, concluded that the age of cut had no influence, but rather the period of the year.

Table 4. Parameters of degradation profiles of white-oat IPR 126 and 95\% confidence interval for each period of harvest

\begin{tabular}{ccccc}
\hline Parameters & 14 & 21 & 28 & 35 \\
\hline$V f_{l}$ & $13.98 \pm 0.76$ & $14.08 \pm 0.51$ & $14.54 \pm 1.700$ & $14.64 \pm 0.94$ \\
$k_{1}$ & $0.08 \pm 7.4410^{-3}$ & $0.08 \pm 5.5610^{-3}$ & $0.08 \pm 7.4410^{-3}$ & $0.08 \pm 2.0210^{-3}$ \\
$k_{2}$ & $0.02 \pm 9.9210^{-4}$ & $0.02 \pm 1.2110^{-3}$ & $0.02 \pm 1.7210^{-3}$ & $0.02 \pm 5.3110^{-4}$ \\
$V f_{2}$ & $12.03 \pm 1.31$ & $12.42 \pm 0.99$ & $13.62 \pm 2.354$ & $12.74 \pm 0.51$ \\
$\lambda$ & $1.68 \pm 0.28$ & $1.90 \pm 0.36$ & $1.86 \pm 0.615$ & $2.32 \pm 0.14$ \\
\hline
\end{tabular}

$V f_{1}$ and $V f_{2}$ are fast and slow gas productions, $(\mathrm{mL} / 0.1 \mathrm{~g} \mathrm{DM}) ; k_{1}$ and $k_{2}$ are fractional rates of the fast and slow pools, respectively; $\lambda$ is the lag time in (hours).

It is important to provide diets with adequate balance between fiber carbohydrates (FC) and non-fiber carbohydrates (NFC) to ruminants, preventing high concentrations of NFC, whose degradation rate is higher, causing a peak of fermentation that would result in a sharp decrease in rumen $\mathrm{pH}$. Ruminal $\mathrm{pH}$ is one of the main determinants of the prevalence of microorganisms on ruminal ecosystem (ØRSKOV \& TYLE, 1990), being directly modified by the diet, as well as the intake of fodder that allows the $\mathrm{pH}$ of the rumen to be adequate for the growth of structural carbohydrate fermenter bacteria and protozoa (OLIVEIRA et al., 2007). According to Van Soest (1994), $\mathrm{pH}$ values below 6.2 hamper the fiber digestion in the rumen by hinder the growth of bacteria that degrade FC. The $\mathrm{pH}$ of the samples incubated in vitro in this study was measured at the end of the incubation period and ranged between 6.8 and 7.0 .

The estimated values of $V f_{1}$ were higher than those of $V f_{2}$ for all treatments (Table
4). Although these data were not statistically analyzed because the difference between $V f_{1}$ and $V f_{2}$ is not the main scope of this work, this result was probably due to the lower fiber content of temperate grasses such as oats, which makes the contribution of the fiber fermentation smaller to the total of fermented carbohydrates. The same pattern was found by Calabrò et al. (2001) using the method of curve subtraction to determine the in vitro gas production of the fibrous and non-fibrous carbohydrate fractions of alfalfa hay and Italian ryegrass + oats hay. In tropical grasses (Pennisetum purpureum Schumach, Brachiaria brizantha and Brachiaria decumbens) Malafaia et al. (1998) found the opposite, ie, $V f_{2}$ higher than $V f_{1}$.

The harvest interval influenced some chemical components of the white oat (Avena sativa L.) cultivar IPR 126 and the degradation rate of the fiber carbohydrates, but, in the conditions of the present study, do not interfere in the lignin content. The forage has a high 
nutritive value especially when managed with 21 days of cutting interval, in southwest region of the Parana state, Brazil.

\section{ACKNOWLEDGEMENTS}

The first author was granted by the Coordenação de Aperfeiçoamento de Pessoal de Nivel Superior - CAPES (Brazil).

\section{REFERENCES}

ABREU, M.L.C.; VIEIRA, R.A.M.; ROCHA, N.S.; ARAUJO, R.P.; GLÓRIA, L.S.; FERNANDES, A.M.; LACERDA, P.D.; GESUALDI JÚNIOR, A. Clitoria ternatea L. as a potential high quality forage legume. Asian-Australasian Journal of Animal Sciences, v.27, n.2, p.169-178, 2014.

ADAMI, P.; PITTA, F.; CHRISTIANO, $S$. R. Pastagem e bovinocultura de leite. Goioerê, PR, Instituto Federal do Paraná, 2012.

BUXTON, D.R. Quality relatedcharacteristics of forages as influenced by plant environment and agronomic factors.

Animal Feed Science and Technology, v.59, n.1, p.37-49, 1996.

CALABRÒ, S.; INFASCELLI, F.; BOVERA, F.; MONIELLO, G.; PICCOLO, V. In vitro degradability of three forages: fermentation kinetics and gas production of NDF and neutral detergent-soluble fractions of forages. Journal of the Science of food and Agriculture, v.82, p.222-229, 2001.
CARVALHO, P.C.F.; SANTOS, D.T.; GONÇALVES, E.N.; MORAES, A.; NABINGER, C. Forrageiras de clima temperado. In: FONSECA, D.M.da; MARTUSCELLO, J.A. (Org.). Plantas Forrageiras. Viçosa, MG: Universidade Federal de Viçosa, 2010. v.1, p.494-537.

CASTRO, G.H.F.; RODRIGUEZ, N.M.; GONÇALVES, L.C.; MAURÍCIO, R.M. Características produtivas, agronômicas e nutricionais do capim-tanzânia em cinco diferentes idades ao corte. Arquivo Brasileiro de Medicina Veterinária e Zootecnia, v.62, n.3, p.654-666, 2010.

DESCHAMPS, F.C. Implicações do período de crescimento na composição química e digestão dos tecidos de cultivares de capim elefante (Pennisetum purpureum Schumach.). Revista Brasileira de Zootecnia, v.28, p.13581369, 1999.

DETMANN, E.; COELHO DA SILVA, J.F.; VÁSQEZ, H.M. HENRIQUES, L.T.; HADDADE, I. R. Cinética da degradação ruminal dos carboidratos de quatro gramíneas tropicais em diferentes idades de corte e doses de adubação nitrogenada: técnica de produção de gases. Revista Brasileira de Zootecnia, v.38, n.1, p.149-158, 2009.

FLOSS, E.L.; PALHANO, A.L.; SOARES FILHO, C.V.; PREMAZZI, L.M. Crescimento, produtividade, caracterização e composição química da aveia branca. Acta Scientiarum. Animal Sciences, v.29, n.1, p.1-7, 2007.

FOX, D.G.; TEDESCHI, L.O.; TYLUTKI, T.P.; RUSSELL, J.B.; VAN AMBURGH, M.E.; CHASE, L.E.; PELL, A.N.; OVERTON, T.R. The cornell net carbohydrate and protein system model for evaluating herd nutrition and nutrient excretion. Animal Feed Science and Technology,v.112, n.1, p.29-78, 2004. 
GRIFFTHS, N. W.; BURNS, H. M. Silage from pastures and forage crops In: KAISER, A. G.; PILTZ, J. W.; GRIFFTHS, N. W. Successful Silage. 2nd ed. Orange, N.S.W. Dairy Australia \& NSW Dept. of Primary Industries, 2004. 419 p. Disponível em:

$<$ http://www.dpi.nsw.gov.au/_data/ass ets/pdf_file/0005/294053/successfulsilage-topfodder-complete.pdf $>$. Acesso em: 10 jan. 2017.

HENRIQUES, L. T.; COELHO DA SILVA, J. F.; DETMANN, E.; VÁSQUEZ, H. M.; PEREIRA, O. G. Frações dos carboidratos de quatro gramíneas tropicais em diferentes idades de corte e doses de adubação nitrogenada. Arquivo Brasileiro de Medicina Veterinária e Zootecnia, v.59, n.3, p.730-739, 2007.

\section{INSTITUTO AGRONÔMICO DO} PARANÁ - IAPAR. Os múltiplos usos da Aveia branca IAPAR 126. 2007. Disponível em:

$<$ http://www.iapar.br/modules/noticias/a rticle. php?storyid $=16>$. Acesso em: 22 de jul. 2013.

JUNG, H.G.; ALLEN, M. S.

Characteristics of plant cell walls affecting intake and digestibility of forages by ruminants. Journal of Animal Science, v.73, n.9, p.27742790, 1995.

\section{KOZLOSKI, G.V. Bioquímica dos}

Ruminantes. $3^{\mathrm{a} e d . ~ S a n t a}$ Maria: Universidade Federal de Santa Maria, 2012, 214p.

KOZLOSKI, G.V.; PEROTTONI, J.; SANCHEZ, L.M.B. Influence of regrowth age on the nutritive value of dwarf elephant grass hay (Pennisetum purpureum Schum. Cv. Mott) consumed by lambs. Animal Feed Science and Technology, v.119, p.1-11, 2005.
LITTELL, R.C.; MILLIKEN, G.A.; STROUP, W.W.; WOLFINGER, R.D.; SCHABENBERGER, O. SAS ${ }^{\circledR}$ for Mixed Models. Cary: SAS Institute Inc., 2006.

\section{MAACK, R. Geografia física do}

Estado do Paraná. Curitiba: Banco de Desenvolvimento do Paraná, 1968. 350 p.

McALLISTER, T.A; BAE, H.D.; JONES, G.A.; CHENG, K.J. Microbial attachment and feed digestion in the rumen. Journal of Animal Science, v.72, n.11, p.3004-3018, 1994.

MALAFAIA, P.A.M.; VALADARES FILHO, S. de C.; VIEIRA, R. A. M.; SILVA, J. F. C.; PEREIRA, J.C. Cinética ruminal de alguns alimentos investigada por técnicas gravimétricas e metabólicas. Revista Brasileira de Zootecnia, v.27, n.2, p.370-380, 1998.

MERTENS, D.R.; ALLEN, M.; CARMANY, J.; CLEGG, J.; DAVIDOWICZ, A.; DROUCHES, M.; FRANK, K; GAMBIN, D.; GARKIE, M.; GILDEMEISTER, B.; JEFFRESS, D.; JEON, C.S.; JONES, D.; KAPLAN, D.; KIM, G.N.; KOBATA, S.; MAIN, D.; MOUA, X.; PAUL, B.; ROBERTSON, J.; TAYSOM, D.; THIEX, N.; WILLIAMS, J.; WOLF, M. Gravimetric determination of amylasetreated neutral detergent fiber in feeds with refluxing in beaker or crucibles: collaborative study. Journal of AOAC International, v.85, n.6, p.1217-1240, 2002.

MONTGOMERY, D. C. Design and analysis of experiments. $6^{\text {th }}$.ed. New York: John Wiley and Sons Co, 2005. $643 p$. 
MOREIRA, A.L.; REIS, R.A.; RUGGIERI; A.C. Avaliação de forrageiras de inverno irrigadas sob pastejo. Ciência e Agrotecnologia, v.31, n.6, p.1838-1844, 2007.

\section{NATIONAL RESEARCH COUNCIL -} NRC. Nutrient Requeriments of Dairy Cattle. $7^{\text {th }}$. ed. Washington: National Academy Press, 2001. 38p.

OLIVEIRA, J.S.; ZANINI, A.M.; SANTOS, E.M. Fisiologia, manejo e alimentação de bezerros de corte. Arquivos de Ciências Veterinária e Zootecnia, v.10, n.1, p. 39-48, 2007.

OLIVEIRA, E. Opções de forrageiras de entressafra e inverno em sistema de integração lavoura e pecuária. In: SULLEITE SIMPÓSIO SOBRE SUSTENTABILIDADE DA PECUÁRIA LEITEIRA NA REGIÃO SUL DO BRASIL, 2., 2002, Toledo. Anais... Maringá: UEM/CCA/DZONUPEL, 2002. p.189-205

ØRSKOV, E.R.; TYLE, M. Energy nutrition in ruminants. Cambridge: Elsevier Science Publishers. 1990. $146 \mathrm{p}$.

PACIULLO, D.S.C. Características anatômicas relacionadas ao valor nutritivo de gramíneas forrageiras.

Ciência Rural, v.32, n.2, p.357-364, 2002.

PAULINO, M. F.; ZERVOUDAKIS, J. T.; MORAES, E. H. B. K; DETMANN, E.; VALADARES FILHO, S. C. Bovinocultura de ciclo curto em pastagens. In: SIMPÓSIO DE PRODUÇÃO DE GADO DE CORTE, 3., 2002, Viçosa. . Anais... Viçosa, MG: Universidade Federal de Viçosa, 2002. p.196.
PIRES, A.J.V.; REIS, R.A.; CARVALHO, G.G.P.; SIQUEIRA, G.R.; BERNARDES, F.T.; RUGGIERI, A.C.; ALMEIDA, E.O. AND ROTH, M.P.T. Degradabilidade ruminal da matéria seca, da fração fibrosa e da proteína bruta de forrageiras, Pesquisa Agropecuária Brasileira, v.41, n.4, p.643-648, 2006.

\section{RIZZI, S.P. Caracteres morfo-}

fisiológicos e produtividade de cultivares de aveia branca. 87p. 2004. Dissertação (M.Sc.) - Universidade Passo Fundo.

SCHOFIELD, P.; PITT, R. E. AND PELL, A. N. Kinetics of fiber digestion from in vitro gás production. Journal of Dairy Science, v.72, n.11, p.2980-299, 1994.

SILVA, F.B. Qualidade nutricional sob corte, pastejo com diferentes alturas de manejo. 65p. 2011. Tese (D.Sc.). - Universidade Estadual do Oeste do Paraná.

SILVA, P.A.; VALADARES FILHO, S.C.; VALADARES, R.F.D.; CECON, P.R.; DETMANN, E.; PAIXÃO, M.L. Valor energético do capim-elefante em diferentes idades de rebrota e estimativa da digestibilidade in vivo da fibra em detergente neutro. Arquivo Brasileiro de Medicina Veterinária e Zootécnica, v.59, n.3, p.711-718, 2007.

SILVA, D.J.; QUEIROZ, A.C. Análise de alimentos: métodos químicos e biológicos. 3.ed. Viçosa: Universidade Federal de Viçosa, 2002. 235p.

SMITH, M. I.; YATSUNENKO, T.; MANARY, M. J.; TREHAN, I.; MKAKOSYA, R.; CHENG, J.; KAU, A. L.; RICH, S. S.; CONCANNON, P.; MYCHALECKYJ, J. C.; LIU, J.; HOUPT, E.; LI, J. V.; HOLMES, E.; 
NICHOLSON, J.; KNIGHTS, D.; URSELL, L. K.; KNIGHT, R.; GORDON, J. I. Gut microbiomes of Malawian twin pairs discordant for kwashiorkor. Science, v.339, n.1, p.548-554, 2013.

SNIFFEN, C.J.; O'CONNOR, J.D.; VAN SOEST, P.J.; FOX, D.G.; RUSSELL, J.B. A net carbohydrate and protein system for evaluating cattle diets. II. Carbohydrate and protein availability. Journal of Animal Science, v.70, n.11, p.3562-3577, 1992.

TOMICH, T.R.; GONÇALVES, L.C.; MAURÍCIO, R.M.; PEREIRA, L.G.R.; RODRIGUES, J.A.S. Composição bromatológica e cinética de fermentação ruminal de híbridos de sorgo com capim-sudão. Arquivo Brasileiro de Medicina Veterinária e Zootécnica, v.55, n.6, p.747-755, 2003.

VAN SOEST, P.J. Nutritional ecology of ruminant. 2.ed. Ithaca: Cornell University Press 1994. 476p.

VAN SOEST, P.J.; ROBERTSON, J.B.; LEWIS, B.A. Methods for dietary fiber, neutral detergent fiber, and nonstarch polyssacarides in relation to animal nutrition. Journal of Dairy Science, v.74, p.3583-3597, 1991.

VAN SOEST, P.J. ROBERTSON, J.B. Analysis of forages and fibrous foods. Ithaca: Cornell University, 1985. 202 p.

VELASQUEZ, P. A. T.; BERCHIELLI, T.T.; REIS, R.A.; RIVERA, A.R.; DIAN, P.H.M.; TEIXEIRA, I.A.M.A. Cinética da fermentação e taxas de degradação de forrageiras tropicais em diferentes idades de corte estimadas pela técnica de produção de gases in vitro. Revista Brasileira de Zootecnia, v.38, n.9, p.1695-1705, 2009.
VIEIRA, R.A.M.; FERNANDES, A.M. A importância de estudos quantitativos associados à fibra para a nutrição e a alimentação de ruminantes. In: $43^{\mathrm{a}}$ Reunião Anual da Sociedade Brasileira de Zootecnia, 43., 2006, João Pessoa. Anais... João Pessoa: Sociedade Brasileira de Zootecnia, 2006. p.258290.

Data de recebimento: 18/08/2015

Data de aprovação: 18/01/2017 